\title{
INFÂNCIA, NATUREZA E AFETOS: O "DESEMPAREDAMENTO" E AS VIVÊNCIAS NO PÁTIO DA EDUCAÇÃO INFANTIL DO COLÉGIO DE APLICAÇÃO DA UFRJ
}

Raianne da Silva Alves Bernardo Thomaz ${ }^{\mathrm{i}}$

Resumo: O presente artigo é fruto de uma pesquisa monográfica para a conclusão do curso de Especialização em Educação Psicomotora e tem por objetivo investigar e refletir sobre crianças, corpos, natureza e "desemparedamento" por meio de uma pesquisa-ação, no pátio da Educação Infantil do Colégio de Aplicação da UFRJ. O trabalho tem por base os estudos em Psicomomotricidade, Educação e Filosofia, o que permite entrelaçar as experiências observadas e a teoria dos autores que se debruçam sobre questões pertinentes a este estudo. A pergunta 'como as crianças experienciam o pátio?' foi propulsora para esta pesquisa, permitiu a busca por respostas e o levantamento de novas questões ao chegar ao campo. Olhar para as crianças brincando na natureza possibilitou a compreensão da construção do conhecimento significativo, que deixa marcas no corpo e permite descobrir o caminho e aventura de experimentar o mundo.

Palavras-chave: Infância; Psicomotricidade; Corpo; Natureza.

\section{CHILDHOOD, NATURE AND AFFECTION: TAKING CHILDREN OUTDOORS AND THE EXPERIENCES IN THE KINDERGARTEN SCHOOLVARD AT COLÉGIO DE APLICAÇÃO OF THE FEDERAL UNIVERSITY OF RIO DE JANEIRO}

\begin{abstract}
: this article is the result of a monographic research for the conclusion of the Specialization Course in Psychomotor Education whose objective is to investigate and reflect about children, bodies and "outdoor experiences" through an action-research in the kindergarten courtyard of the UFRJ School of Application. The research is based on studies in Psychomotricity Education and Philosophy which allowed to connect the observed experiences and the theory of the authors investigate and the relevant questions for this study. The question: "How do children experience the courtyard?" it was the main question to start to study this subject and allowed the search for answers and the raising of new questions when we were in the field. Looking at children playing in nature has enabled understanding of the construction of meaningful knowledge, which leaves marks on the body and allows you to discover the way and adventure of experiencing the world.
\end{abstract}

Keywords: Childhood; Psychomotricity; Body; Nature

2020 Thomaz. Este é um artigo de acesso aberto distribuído sob os termos da Licença Creative Commons Atribuição Não Comercial-Compartilha Igual (CC BY-NC-4.0), que permite uso, distribuição e reprodução para fins não comerciais, com a citação dos autores e da fonte original e sob a mesma licença. 


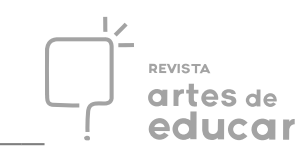

\section{Infância natureza e afetos}

Este texto, em linhas gerais, situa-se no campo dos debates sobre Educação Psicomotora, tendo como foco o trabalho corporal, desenvolvido na área educacional, pelo viés dos estudos da Psicomotricidade, Filosofia, Pedagogia e legislação na área da Educação. Com o conceito de "corpos dóceis", de Foucault (2009), em sua obra 'Vigiar e punir: nascimento da prisão', observei vivências que vão na contramão dessa “docilização" dos corpos de crianças e professores, buscando, segundo Tiriba (2018), o "desemparedamento" dos atores sociais presentes na escola.

Dessa forma, para esta pesquisa, o olhar esteve voltado para as crianças, seus movimentos, seus corpos e o contato delas com a natureza em uma escola pública federal da cidade do Rio de Janeiro. Por sua vez, tais crianças estão em relação com adultos, prioritariamente professores, que trabalham diariamente com elas no cotidiano escolar. Portanto, o olhar se voltou também para as relações entre esses corpos (adultoscrianças) no contexto da Educação Infantil, percebidas pelo olhar da Psicomotricidade.

Diante desse contexto, o trabalho traz as minhas inquietações em relação ao tema que desejo estudar, pesquisar e refletir por meio das seguintes questões: quais são as vivências do espaço externo? Como as crianças experienciam o pátio? Quais as potencialidades das crianças em espaços que permitem contato com a natureza? Por essas questões, busquei observar como as crianças têm em si o desejo do contato com a água, com a terra, com os animais, entre outros elementos que nos compõem como seres.

Por meio de uma pesquisa-ação, no pátio da Educação Infantil do Colégio de Aplicação da Universidade Federal do Rio de Janeiro (EEI-UFRJ), com o grupo 5 (crianças de quatro anos a quatro anos e onze meses), houve a observação participante, de forma que a pesquisa se concretizou para além do estudo bibliográfico também presente, com autores de diferentes áreas para dialogar com a presente pesquisa, com o marco teórico composto por referenciais da área da Psicomotricidade, Filosofia e Educação. Torna-se importante ressaltar que, para preservar as crianças, os nomes presentes aqui são fictícios e as imagens estão distorcidas. 


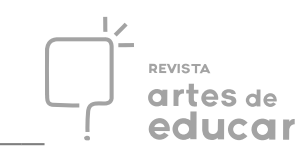

\section{O corpo pelo olhar da Psicomotricidade}

O que é o corpo? O que é o corpo na escola? Como esse corpo se relaciona? Pretendo, no decorrer desta escrita, trazer possíveis respostas para essas perguntas, pela ótica da Psicomotricidade. Porém, antes de defender o que acredito como corpo na escola, busco referências em Foucault, para exemplificar como essa instituição vem, há séculos, aprisionando os corpos, transformando crianças em alunos. Foucalt (2009, p.173) descreve o espaço escolar como uma máquina de ensinar, mas também de vigiar, de hierarquizar, de recompensar. Ao mencionar o corpo nesses espaços, esse autor (idem, p.163) explicita que é dócil um corpo que pode ser submetido, que pode ser utilizado, que pode ser transformado e aperfeiçoado.

Na contramão do corpo como dócil e útil, defendo o corpo integral, que não se divide em partes, que se complementa nas relações com os outros seres e consigo mesmo. Corpo que se movimenta, que é potência e vida, como nos alertam Mastrascusa e Franch (2016, p.111), um corpo agindo, um corpo ator, um corpo atuante, vivo, portanto, constituído por meio das relações do sujeito com o outro - CORPO SUJEITO.

Segundo Lapierre e Aucouturier (2004, p.34), disponibilidade, respeito e aceitação são [...] qualidades essenciais da pedagogia. Portanto, tais condições precisam ser percebidas nas instituições escolares em suas práticas pedagógicas. Ao estar disponível para perceber o outro, ou seja, a criança; ao respeitar os seus anseios, desejos e aceitá-los, a escola vai abrindo seu horizonte para uma educação em que os diferentes atores têm espaço de expressão, de escuta e de fala, mesmo que sem palavras, no caminho de uma educação que compreende o ser em sua totalidade, que se sensibiliza na relação com o outro, que possibilita o ato de aprender e conhecer significativamente pela alegria e pelos desejos infantis. Nessa perspectiva, o caminho se dá na potência dos corpos, como sugerem esses autores (idem, p. 20): nós queremos trabalhar com aquilo que há de positivo nas crianças; nos interessamos pelo que ela sabe fazer, e não pelo que ela não sabe fazer. Nesse caminho, elas nos convidam a vivenciar encontros potentes, nos mostram caminhos para viver a educação de forma significativa. 


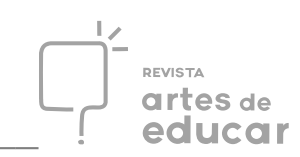

A potência também se dá no movimento e, em seu estudo sobre Henri Wallon, Galvão (2014, p.112) explicita que é preciso deixar de olhar o movimento somente como transgressão e fonte de transtornos, buscando enxergar nele sua multiplicidade de dimensões e significados. É preciso, enfim, olhar a criança como ser concreto $e$ corpóreo, uma pessoa completa. Com essa afirmação, cabe destacar o olhar sensível nas instituições escolares, já que lidamos, segundo Lapierre e Aucouturier (2004, p.39), com a constatação de que o corpo em movimento, na sua agitação emocional $e$ criadora, não é admitido na escola, senão nas 'recreações', sob o olhar do professor que, a rigor, observa, evitando misturar sua autoridade a esses jogos pueris.

Ao considerar o contexto em que essa afirmação foi escrita, pensamos em instituições de cultura europeia de décadas passadas, no entanto, ainda vivemos com a herança de uma cultura eurocêntrica, enraizada em muitas práticas escolares aqui no Brasil, até os dias de hoje, como ressalta Tiriba (2018).

Dessa forma, convidamos os educadores a experimentar olhar para o movimento sob a ótica da Psicomotricidade na escola. Com a contribuição de Lapierre e Aucouturier (2004, p.41), podemos, portanto, falar de uma 'pulsão do movimento' primitiva e fundamental, que está na própria base da pulsão de vida. Com isso, compreendemos o movimento como vida e, assim, podemos perceber a escola como um espaço para movimentar-se, um espaço não só para viver, como, principalmente, para viver em alegria.

Olhar para as crianças é uma das principais ações sugeridas neste estudo, uma vez que, segundo Mastrascusa e Franch (2016, p.126), por meio do olhar, o corpo do outro se torna uma imagem visual que penetra em mim... E, pouco a pouco, a criança percebe que a sua própria imagem também penetra o corpo do outro e nele provoca reações. Há importância também no escutar. De acordo com os autores mencionados (idem, p.128), compreendermos que a necessidade mais profunda da criança, como a de todo ser humano, é a de ser escutada, inclusive na intimidade dos sentimentos, que, para ela mesma, não são conscientes. Dessa forma, a escuta e o olhar sensíveis para o sujeito são fundamentais para psicomotricistas e educadores e para os educadores psicomotricistas como eu.

Defendo uma psicomotricidade que não é uma disciplina com tempo determinado na grade curricular. Intercedo pela Educação Psicomotora no dia a dia das 


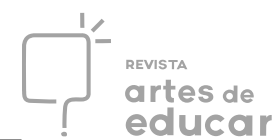

escolas, transpassando a rotina, as atividades, vivências e experiências por meio da escuta e do olhar sensível dos educadores. Ainda de acordo com esses autores (ibidem, p.163), sentimos a necessidade da inclusão na escola de um corpo vivido, e não só um corpo racional e consciente. Para conhecer o mundo, precisamos nos entregar por completo. Essa é também a essência do conhecimento.

Para os psicomotricistas, o corpo é relacional, expressivo, como afirma Galvão (2014, p.99): expressar-se significa exteriorizar-se, colocar-se em confronto com o outro, organizar-se. Nesse caminho, vamos na contramão da opressão, do sujeito descaracterizado, que foge da escola por esse não ser o seu lugar. Quero ver crianças que se encontram e se emocionam no contato com o mundo.

Ao mencionar as emoções, penso no lugar que ela ocupa na escola, uma vez que, de acordo com essa autora (idem, p.64), elas nutrem-se do efeito que causa no outro, isto é, as reações que as emoções suscitam no ambiente funcionam como uma espécie de combustível para sua manifestação. Novamente, a escuta e olhar se fazem presentes e necessários na escola. É potente nutrir a emoção, o outro, pois, seja ele criança, adolescente ou adulto, aprende a emocionar-se no contato com seus pares.

Vale lembrar que, paras Mastrascusa e Franch (2016, p.67), etimologicamente, emoção significa essencialmente movimento, expressão motora feita através da conduta, tanto se for linguagem verbal como não verbal. Emoção não é apenas um ato motor, é movimento, é relação, é expressão e faz parte do ser, que se emociona nas relações. Ao se emocionar, a criança faz reflexões.

Vivenciar, permite se emocionar, aprender, compreender e conhecer, por isso, segundo Lapierre e Aucouturier (2004, p.32):

Não basta mobilizar a musculatura voluntária para executar um ato reflexivo, o que coloca em jogo somente o sistema cortical, mas deve ser mobilizado também, e principalmente, o sistema hipotalâmico de modulação do tônus emocional. Isso só pode ser feito a partir de uma vivência cuja dimensão afetiva real, profunda e espontânea não esteja excluída.

A escola que aprisiona, dicotomiza seres humanos e natureza, que inviabiliza as emoções, por serem reações expostas corporalmente, nega o ser e a sua essência.

Importante destacar que, de acordo com Mastrascusa e Franch (2016, p.163), os comportamentos corporais espontâneos que exprimem a afetividade ou a emoção são Revista Interinstitucional Artes de Educar. Rio de Janeiro, V. 6, N.1-pág. 204-231 janeiro-abril de 2020: “Educação: Corpo em movimento II." - DOI: 10.12957/riae.2020.45751 


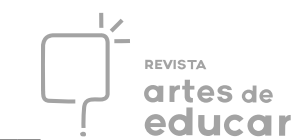

considerados como fraqueza ou mesmo desprezados pela racionalidade cognitiva dominante. Acredito na escola como lugar de encontro, como lugar do ser completo, que além de "ser" é "pensante” ou ser 'sentipensante'. Esse ser só é capaz de pensar por ser capaz de sentir. Como afirma Queirós (2012, p.9), os sentidos têm raízes pelo corpo inteiro.

Nas palavras de Mastrascusa e Franch (2016, p.111), vislumbramos um corpo integrante da globalidade do ser humano, um corpo agindo, um corpo ator, um corpo atuante, vivo, portanto, constituído por meio das relações do sujeito com o outro. Seja professor, seja criança, seja outro adulto, é fundamental para que se constitua.

Nessas relações, entramos em contato com o outro, com o objeto e com nós mesmos, por meio do diálogo corporal, que constitui a fase inicial e fundamental da comunicação com o mundo, como salientam Lapierre e Aucouturier (2004, p.35).

Como já descrito, movimento é vida, e o ser se desenvolve no mundo, reconhece o seu espaço e se integra ao ambiente por meio do diálogo corporal. Compreendo o corpo como a porta de entrada para o mundo, para a vida e para alegria.

Ao escrever sobre a luta pela liberdade das crianças e de seus movimentos, um educador pode se questionar: o que é ser livre? O que é aprisionar? Ser livre é fazer o que quer a todo momento? Pela minha experiência como professora e pesquisadora na Educação Infantil, percebo a liberdade na escola como um processo, que se relaciona com alguns limites importantes para viver em sociedade.

Em relação aos limites, que são questionados pelos educadores, busco referência em Mastrascusa e Franch (2016, p.96) ao explicitarem que colocar limites não é 'castigar', é acolher [...]. A mensagem que recebe o pequeno deve ser não a isso que fazes, mas nunca um não a ti porque fazes isso.

O corpo, pelo olhar da Psicomotricidade, foi descrito brevemente neste texto. Em síntese, somos movimento, expressão, emoção, relação, encontro, vida, potência e alegria. Esses conceitos são bases para o que escrevo, são bases para minha prática, são bases para o presente estudo.

\section{O corpo como ambiente natural}

Terra, sol, ar e água são elementos que representam o mundo natural, elementos que se completam, que se transformam, que se relacionam. Terra e água, juntos, por 


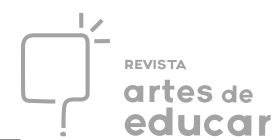

exemplo, tornam-se lama. Esses elementos nos constituem como seres? Fazem parte do que somos? O ser humano é natureza? De acordo com Tiriba (2018, p.18), crianças são seres de cultura e simultaneamente, da natureza. Em outro texto, Profice e Tiriba (2014, p.47) reafirmam a resposta à questão, explicitando que os seres humanos são, simultaneamente, seres de cultura e de natureza, e o pertencimento à natureza foi se perdendo no processo de produção da visão de mundo moderna.

Seres humanos são seres da natureza, portanto, nosso corpo é ambiente natural. Anseia pela água, por ver e estar em contato com o verde das árvores e das folhas. E as árvores coloridas na primavera? Como essas me chamam à atenção! Como as folhas caídas no chão, colorindo o percurso que passo são especiais para mim! Confesso que, por alguns anos, caminhei sem dar importância ao que estava ao meu redor, esquecendo a minha alegria da infância em brincar com lama e com água, aos domingos, na casa da minha avó. A correria do dia a dia, o asfalto que chegou em meu bairro no final de minha infância, o anseio por estudar, o estudar que não contempla a natureza - estudar Biologia e Geografia era só por meio dos livros - não era significativo para mim. Inclusive, não tenho boas memórias dessas aulas, na qual eu apenas copiava, decorava e respondia aquilo que já estava posto e pronto pelos professores. Eu reproduzia o produto dos livros didáticos.

Conto um pouco de minha história para dizer que fui ensinada a abandonar o mundo natural ao qual pertencemos, mas tive o privilégio de começar a me reconectar com ele, como professora da Educação Infantil, quando vi o interesse de crianças, de um ano e meio de idade, pela água, pelas folhas e gravetos caídos no pátio da escola. Fui professora desse grupo no ano de 2018, trabalhei, aprendi, vivenciei, brinquei na água e na terra.

Aprendi a respeitar os anseios das crianças pelo contato com o mundo natural, aprendi também a potencializar esse vínculo, planejando momentos para que a interação não fosse refreada. Profice (2016, p.52) afirma que a educação infantil deve se voltar para a conexão das crianças com seus corpos e ambientes vivos, plenos de seres que convocam para a interação e atiçam a curiosidade e o pensamento.

A educação para a primeira infância, que respeita os desejos infantis, que escuta as crianças, que repensa a educação na práxis cotidiana, que potencializa os sentidos da ação, segundo Schaefer (2016 p.9), percebe que há uma potencialidade a ser valorada 


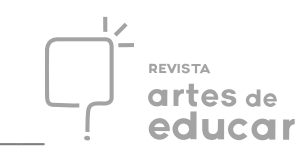

nos espaços de Educação Infantil. São muitas crianças nos convidando a compartilhar com elas os desvios desses caminhos que nos ajudam a estranhar o percurso, a rever trajetórias, a perceber lugares nunca visitados.

Como ambiente natural, faz-nos repensar os caminhos que trilhamos na educação, faz-nos buscar sentido ao que vivemos. Segundo Guattari (2001, p.16):

o sujeito não é evidente: não basta pensar para ser, como o proclamava Descartes, já que inúmeras outras maneiras de existir se instauram fora da consciência, ao passo que o sujeito advém no momento em que o pensamento se obstina em apreender a si mesmo.

Esse autor (idem, p.25) sinaliza que, mais do que nunca, a natureza não pode ser separada da cultura, e precisamos aprender a pensar 'transversalmente' as interações entre ecossistemas, mecanosfera e Universos de referência sociais e individuais. Schaefer (2016, p.8) nos possibilita saber que Spinoza propôs bons encontros para nos potencializarmos $e$, consequentemente, favorecermos a potencialização de uma essência única da qual fazemos parte: a natureza.

Os autores que escrevem sobre a relação com o mundo natural me permitem sintetizar que somos natureza, fazemos parte da natureza e necessitamos do contato com ela. Nesse cenário, Guattari (2001, p.8) explicita a articulação ético-política - a que chamo ecosofia - entre os três registros ecológicos (o do meio ambiente, o das relações sociais e o da subjetividade humana). A ecosofia, conceito desse autor, refere-se à importância das relações para o ser humano. Relação com o ambiente do qual ele faz parte, com os seres que estão próximos a ele e com ele mesmo.

Crianças que são natureza, natureza como tudo que nos cerca, nas palavras de Tiriba e Profice (2014, p.49), crianças e jovens como seres biofílicos; ou seja, seres que se desenvolvem plenamente em interação com elementos do mundo natural do qual são parte. A escola que separa crianças e natureza não permite o desenvolvimento pleno do ser. Como se desenvolver longe da sua essência? E como acontece a ação de aprender, que não se resume na aquisição de conhecimentos prontos, mas na construção destes a partir das vivências e experiências?

Na Educação Infantil, o currículo não se resume à grade curricular, que, por vezes, isola as áreas do conhecimento. No mundo, está tudo interligado e, assim, vivenciamos a primeira etapa da Educação Básica. A justificativa dessa concepção pode Revista Interinstitucional Artes de Educar. Rio de Janeiro, V. 6, N.1-pág. 204-231 janeiro-abril de 2020: “Educação: Corpo em movimento II." - DOI: 10.12957/riae.2020.45751 
se pautar nas Diretrizes Curriculares Nacionais para Educação Infantil (BRASIL, 2009, Art.3), que define o currículo como o conjunto de práticas que buscam articular as experiências e os saberes das crianças com os conhecimentos que fazem parte do patrimônio cultural, artístico, ambiental, científico e tecnológico.

A educação como o ato de viver para conhecer, de experienciar e sentir se justifica no currículo da Educação Infantil, que articula experiências e saberes, que permite estar em contato com o mundo natural ao qual as crianças pertencem. Para Tiriba (2018, p.229), na perspectiva da complexidade, viver e conhecer são mecanismos vitais. Conhecemos porque somos seres vivos, e isso é parte dessa condição. Conhecer é condição de vida na manutenção da conexão com o universo de que somos parte.

Como já foi explicitado por Profice (2016, p.184), as crianças são seres da natureza e por isso não podemos privá-las de interações cotidianas com demais seres $e$ ambientes naturais. Como natureza, as crianças necessitam do contato com água, água como fonte de vida, para além do banho e do lavar as mãos, água para brincar, para estar em contato, para cuidar das plantas, para dar banho em bonecas, para o banho coletivo de mangueira, para fazer lama, para colorir com tinta, para molhar os amigos e se molhar. As crianças precisam estar com os pés no chão, sentir a terra, fazer bolo, comida, café, ou seja, imaginar e criar no brincar livre na natureza.

Segundo Tiriba (2018, p.234), precisamos relembrar aos seres que a natureza é um organismo vivo: não se trata, portanto, de defender a vida sobre a Terra, mas de afirmar que a Terra é a própria vida. Se somos natureza e a Terra é a vida, o mundo natural retratado neste texto é a vida de cada um dos seres presentes no planeta, sejam humanos ou não humanos. As crianças são apaixonadas pelos pássaros, formigas, cigarras, aranhas, por tudo que as aproxime de sua própria essência - a natureza da qual fazem parte. Esse é o seu interior e, aos poucos, os adultos, pais e professores tiram delas o direito à natureza a qual pertencem. Essa autora (idem, p.204) salienta que:

Diante de uma cultura que silencia a unidade e valoriza a dicotomia, afirmamos, desde a primeira infância, a importância da educação ambiental como processo que reintegra o que essa cultura artificialmente separou, isto é, que religa seres humanos e natureza, razão e emoção, corpo e mente, conhecimento e vida. 


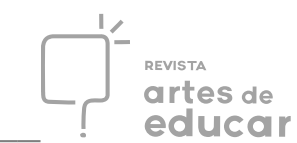

Terra, sol, ar, água e crianças são natureza! São elementos que se unem, que se transformam, que necessitam um do outro para a existência plena. Precisamos dos quatro primeiros elementos para viver plenamente, e as crianças nos mostram a importância da relação com os outros elementos naturais, além do nosso próprio corpo e do contato com outros seres humanos. O contato com a natureza nos humaniza!

\section{O pátio da educação infantil do Colégio de Aplicação da UFRJ: relações entre corpos em um ambiente desemparedado}

Liberdade! Encontros, encantamentos, possibilidades, potência, reinvenção, alegria, sorrisos, terra, água, lama, crianças, brincadeiras, quantas palavras podem ser usadas para definir o pátio da Educação Infantil do Colégio de Aplicação da UFRJ? A partir de minhas vivências nesse espaço, percebo que não há uma palavra que possa defini-lo, mas liberdade e relações conseguem representá-lo.

O pátio da nossa escola é imenso, como um grande quintal, que possibilita as crianças, que hoje vivem em apartamentos, em espaços fechados e emparedados, se libertarem ao descer a rampa da escola. Percebo a rampa como um portal que possibilita ir para outra dimensão, uma dimensão livre de tetos e paredes, que possibilita estar sobre a terra e abaixo do céu, no contato com o ar, com sol e brincando com a natureza. A imaginação das crianças flui sem que sejam podadas por adultos, pois elas inventam e reinventam conexões com elas e com os que estão ao seu redor.

O que vi como pesquisadora e que vejo como professora dessa instituição são vários grupos que, independentemente da idade, se unem, compartilhando interesses, e assim ocupam cada pedaço do que chamo aqui de nosso "grande quintal". Manoel de Barros (2008) já afirmou: "meu quintal é maior do que o mundo" e hoje escrevo com esse verso que o quintal da Educação Infantil do Colégio de Aplicação da UFRJ é o nosso mundo e, nesse mundo, cabem as nossas emoções, nossas relações, brincadeiras e invenções. As crianças são sujeitos, são corpo e natureza. 


\section{Caminhos percorridos entre paredes e sem paredes}

Para enriquecer as reflexões, optamos pela metodologia de observação participante, no pátio da Educação Infantil do Colégio de Aplicação da Universidade Federal do Rio de Janeiro (Cap. EI-UFRJ), com o grupo 5 (16 crianças de quatro anos a quatro anos e onze meses). Foram 6 encontros no mês de agosto de 2019, que foram documentados por registros escritos em um caderno de campo, registros gráficos feitos pelas crianças, registros fotográficos e audiovisuais e transcrições de gravações de momentos de diálogos com as crianças, possibilitando o resgate do vivido para enriquecer este estudo no entrelaçamento da teoria com a prática.

O recorte para a pesquisa foi necessário, porém difícil. Por conhecer e trabalhar na instituição, tenho uma visão geral dos grupos da escola. A opção pelo grupo 5 (quatro anos a quatro anos e onze meses) teve, como objetivo, problematizar a concepção de Educação Infantil como uma preparação para o Ensino Fundamental. Tiriba (2018) explicita que, desde 1974, os documentos oficiais de educação, em nível nacional, atribuíram a pré-escola um papel compensatório para que as crianças enfrentassem futuramente o Ensino Fundamental com as mesmas condições de crianças com classes socioeconômicas favorecidas. A intensão do que escrevo aqui é ir na contramão dessa perspectiva, mostrando a Educação Infantil como alegria, com bons encontros, em espaços ao ar livre, em relação com o meio ambiente, com outras crianças e adultos que fazem parte da instituição. Este trabalho procurou perceber a criança como o que ela é hoje e não o que ela será no futuro.

Para escrever este texto foi preciso estabelecer um caminho metodológico composto por observação participante, no qual, em alguns momentos, fui convidada a brincar junto, planejar e vivenciar com as crianças experimentações de conexão com a natureza. Também houve dois momentos em que pude propor vivências psicomotoras, que serão descritas nesta parte. Por fim, trago um pouco da produção de registros gráficos realizados pelas crianças do Grupo 5.

Para além da metodologia do campo, já descrita, trago autores de diferentes áreas para dialogar com a presente pesquisa. Nosso marco teórico é composto por referenciais da área da Psicomotricidade, Filosofia e Educação. 


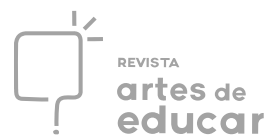

Apesar de nosso objetivo não ser modificar o campo, mas sim de aprender com ele e possibilitar a reflexão dos professores sobre as relações que ocorrem no pátio da instituição, este trabalho é baseado na metodologia da pesquisa-ação, compreendida como uma perspectiva em que, segundo Dione (2007, p.31) se pretende fundamentalmente reduzir a distância entre teoria e prática, dando conta da distância que se criou, em vários campos, entre reflexão teórica e prática profissional.

Nesse sentido, a intenção desta pesquisa é a de refletir sobre a prática, aprender com ela e, com isso, construir conhecimento na relação entre teoria e prática, a nossa práxis. Pensamos na teoria construída no chão da escola com a observação das crianças e de seus professores.

\section{A importância do pátio na Educação Infantil do Colégio de Aplicação da UFRJ}

A Educação Infantil do Colégio de Aplicação da Universidade Federal do Rio de Janeiro foi inaugurada em 24 de junho de 1981. São 38 anos de histórias e reinvenções, inicialmente criada como forma de acolher os filhos dos servidores, numa perspectiva assistencialista. Em 2013, abriu as portas da instituição para todas as crianças, tendo o sorteio como forma de acesso por meio de discussões acerca da Resolução $n^{\circ} 1$ de 10 de março de 2011, que fixou normas de funcionamento das Escolas de Educação Infantil das Unidades ligadas à Administração Pública Federal direta, suas autarquias e fundações pelo Conselho Nacional de Educação na Câmara de Educação Básica (BRASIL, 2011), que, em seu artigo primeiro, pontua a necessidade de oferecer igualdade de condições para o acesso e permanência de todas as crianças na faixa etária que se propõem a atender (BRASIL, 2011, Art. 1 apud EEI-UFRJ, s/d).

De acordo com o site da instituição (EEI-UFRJ, s/d), ela:

tem um importante papel a desempenhar em termos de formação profissional em diversas áreas, especialmente na formação de professores. A unidade também atua como referência na Educação Infantil, desenvolvendo seu trabalho pedagógico com crianças e suas famílias pautado nas Diretrizes Curriculares Nacionais para a Educação Infantil. 


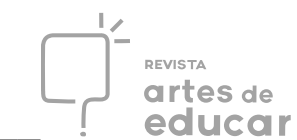

Nesse sentido, a escola é um espaço de referência na Educação Infantil, pautada no tripé pesquisa, ensino e extensão. Acredito que não existe escola perfeita, mas buscamos ser o lugar da educação pautada na alegria, nos encontros, nas interações e brincadeiras. Com um prédio doado há mais de trinta anos e que não foi construído para ser uma escola de crianças, a nossa instituição não tem um espaço físico adequado para os encontros, para as potencialidades. Os educadores fazem com que isso aconteça por meio de planejamentos e reflexões. Apesar desse fator, o nosso pátio é rico em possibilidades e espaços.

O pátio do Cap. EI-UFRJ é arborizado, proporcionando encontros com as árvores e entre pessoas, debaixo de sombra em dias quentes. Há concreto no chão, mas há partes de terra e grama, há a colina, na qual as crianças sobem, descem e rolam. Há pessoas, crianças durante o dia todo, encontros, há potência e, por isso, ele é importante para as crianças e professores. O espaço que chamo de nosso grande quintal é garantido às crianças diariamente pelos professores. O que fiz neste trabalho foi refletir sobre a importância de garantir esse espaço, olhando para as relações entre crianças e crianças com os adultos, além dos encontros com a natureza da qual fazemos parte para escrever, no diálogo com a teoria, a importância das crianças estarem em espaço ao ar livre, de poderem movimentar seus corpos sem que seus desejos sejam podados.

\title{
Pátio: relações entre corpos em um ambiente desemparedado
}

\author{
Uso a palavra para compor meus silêncios. \\ Não gosto das palavras \\ fatigadas de informar. \\ Dou mais respeito \\ às que vivem de barriga no chão \\ tipo água pedra sapo.
}

Manoel de Barros (2008)

As palavras que vivem de barriga no chão, as palavras que fazem sentido e as que voam como passarinhos são palavras carregadas de sentidos e emoções. Ao fechar os olhos e pensar em água, em pedra, em sapo, passam inúmeras imagens na minha cabeça, que, na maioria das vezes, são lembranças da infância que tive. Manoel de Barros (2008) é uma das referências do meu desejo em pesquisar as relações das Revista Interinstitucional Artes de Educar. Rio de Janeiro, V. 6, N.1- pág. 204-231 janeiro-abril de 2020: “Educação: Corpo em movimento II." - DOI: 10.12957/riae.2020.45751 


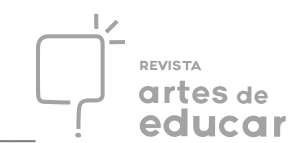

crianças em espaços ao ar livre. Seus poemas, em destaque, $O$ apanhador de desperdícios, representa o interesse das crianças pelo contato com a natureza, o que conceitualmente é definido por Tiriba (2018, p.193) como biofilia, ou seja, uma tendência a aproximar-se, uma atração inata dos seres humanos pela natureza, a união com mundo natural e seus seres. Partindo desse conceito, esta pesquisa traz relatos e descrições dos encontros com dezesseis crianças de quatro a cinco anos no pátio da Educação Infantil do Colégio de Aplicação da UFRJ, compreendendo as crianças como sujeitos corpóreos e sujeitos naturais.

Como professora da escola, as crianças me conheciam dos espaços que compartilhamos. Nosso primeiro contato de pesquisa foi na sala de referência do grupo. As professoras colocaram no planejamento um tempo para que conversássemos na roda sobre a pesquisa. Assim que entrei, começaram as falas: "quem é?", "ela é professora do grupo um" (na verdade, fui professora dos bebês, do grupo dois no ano anterior e essa era a referência que tinham de mim). Entrei na sala, e as professoras finalizavam uma atividade de fotografia com as crianças. Aproximei-me de um grupo que estava sentado na mesa e disse que iria contar na roda o que estava fazendo naquela sala, e uma criança me perguntou: “- Por que não fala agora?". E eu disse que era uma novidade, um segredo a ser desvendado.

Logo, as professoras Laura e Marta organizaram a roda e me convidaram para apresentar a pesquisa e solicitar o consentimento das crianças (figuras 1 e 2).

\footnotetext{
Pesquisadora : "- Boa tarde! Eu sou professora do grupo quatro."

Crianças: "- Não somos o grupo quatro."

Pesquisadora: "- Sim, mas eu soube que vocês gostam muito de brincar no pátio. Por isso quero fazer pesquisa com vocês. Vocês sabem o que é pesquisa?"

Crianças: “- Não."
}

Então, mostrei imagens de crianças brincando com panelinhas, folhas, terra, água e brincando de roda, expliquei-lhes que minha intenção era a de observar as brincadeiras delas no pátio, fotografar e escrever sobre elas e tirar fotos como as que mostrei em nossa roda de conversas.

\footnotetext{
Pesquisadora: "- Posso fazer pesquisa com vocês?" Crianças: “- Sim!” Responderam sorrindo.

Pesquisadora: “- Então, levanta a mão quem quer participar da pesquisa." Todas as treze crianças presentes levantaram a mão.
} 
Voltamos a conversar sobre as imagens.

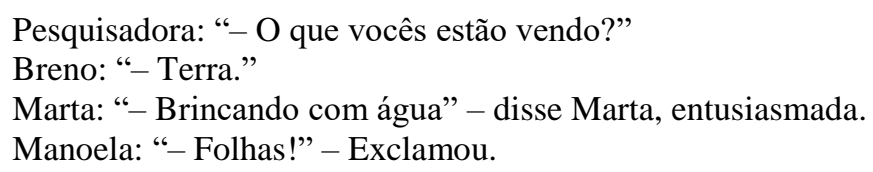

Minha intenção inicial era escrever o que as crianças iam falando num cartaz, no qual elas assinariam o consentimento da pesquisa. Mas, ao escrever lama, água e terra, as crianças começaram a relacionar as letras com os seus nomes e pediram para escrever. Nesse momento, expliquei que elas assinariam nesse papel uma autorização, permitindo que eu tirasse fotos e escrevesse sobre elas. Ao finalizar o momento da roda, uma parte do grupo de crianças exclamava: “- Pátio! Pátio! Pátio!”

Figura 1 - Roda de conversas

Figura 2 - Observando brincadeiras

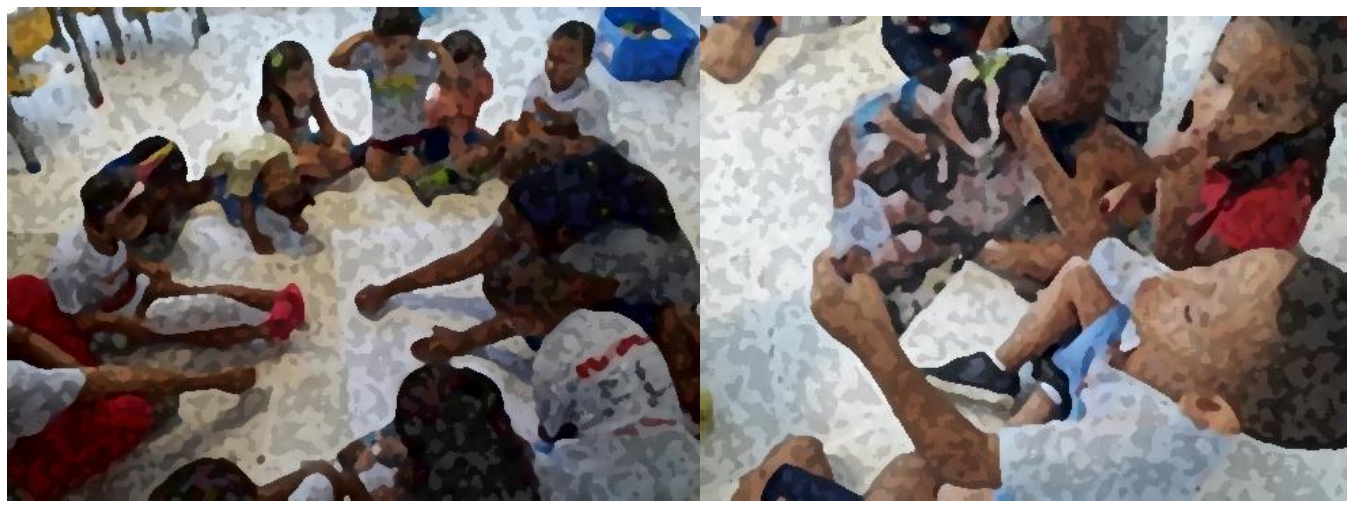

Fonte: Thomaz (2019)

Fonte: Thomaz (2019)

Os três primeiros dias foram momentos de observação, mas, na relação com as crianças, fui convidada a brincar junto. Em alguns momentos, gravei as brincadeiras em áudio para transcrever as falas das crianças. Foram bons encontros, momentos em que pude observar a potencialidade de suas criações. Segundo Mastrascusa e Franch (2016, p.117), com a vivência simbólica no brincar livre espontâneo, as crianças se desenvolvem através das atividades que vão vivenciando, conscientizando seu corpo, as partes entre si e em relação ao mundo exterior.

No brincar, as crianças se relacionam corporalmente, criam, inventam e imaginam diversas possibilidades de conexão e conhecimento.

O primeiro contato para observar foi difícil. Ao chegar ao pátio, as crianças procuraram diversos caminhos, espalharam-se e escolheram espaços diferentes para Revista Interinstitucional Artes de Educar. Rio de Janeiro, V. 6, N.1-pág. 204-231 janeiro-abril de 2020: “Educação: Corpo em movimento II." - DOI: 10.12957/riae.2020.45751 


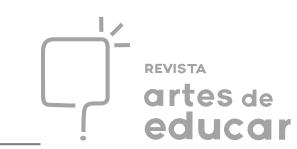

brincar livremente. Então, fui caminhando, observando os grupos que se formavam e tentando me aproximar deles. Enquanto procurava me encontrar com as crianças, Joaquim se aproximou e disse: “-Ei! Eu vou subir na árvore”! Ele saiu correndo e sentou-se no balanço, e eu me aproximei do balanço e perguntei: “- Já subiu na árvore"? E ele me respondeu: “- Ainda não, ela está ocupada com outras crianças". Nesse momento, ele procurou a professora e disse: “- Laura, eu quero brincar, me ajuda a subir"?. Após o movimento da árvore, ele tentou chamar minha atenção novamente, iniciou comigo a brincadeira do "você duvida": "-Você duvida eu subir ali”?; “-Você duvida eu ir correndo até os pneus?”; “-Você duvida eu subir na árvore"?. Entrei na brincadeira, respondendo a todos os questionamentos. "- Duvido"!; “-Duvido”!; e “- Duvido”!. Por fim, ele subiu numa árvore e gritou: “- Ei! Eu aqui!”; “Vem cá!". Nesses momentos, percebi que Joaquim queria criar vínculo e, nos seis dias em que me inseri no grupo para pesquisar, ele esteve sempre presente, procurando se relacionar comigo e com as experimentações a que propus.

No brincar com a natureza, em espaço desemparedado, no pátio da escola, surgem, entre diálogos, inúmeras possibilidades de conhecer, vivenciando o mundo. Para Tiriba e Profice (2014, p. 64), "quando se encontram em ambientes naturais, as crianças partem para a sua exploração, por meio de uma manipulação sensitiva e motora". A manipulação do ambiente natural, em espaços abertos, promove ao corpo a relação com os outros seres e com o mundo, podendo, assim, construir conhecimentos, criar narrativas e possibilitar sua potência criadora. Nesse sentido, mostramos na prática o que já escrevemos no capítulo anterior: o corpo que tem voz e vez, que se coloca no espaço e aprende, se relacionando com ele.

Para melhor organizar os registros pela prática, dividi os momentos vivenciados com as crianças em alguns temas, conforme apresentado a seguir.

O escorrega de formigas no telhado...

Estava observando o brincar livre das crianças quando percebi um grupo pegando formigas. Aproximei-me para compreender melhor o que estava acontecendo. Melissa e Breno colocavam formigas dentro de uma cabeça de tigre (brinquedo de plástico sem o corpo). Fiquei curiosa e indaguei as crianças: “- $O$ que vocês estão 


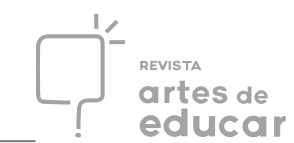

fazendo"? Caíque, vendo-me com a caneta e papel, perguntou: “-Você vai continuar desenhando?”, e sem que eu pudesse responder, ele iniciou um diálogo com o grupo:

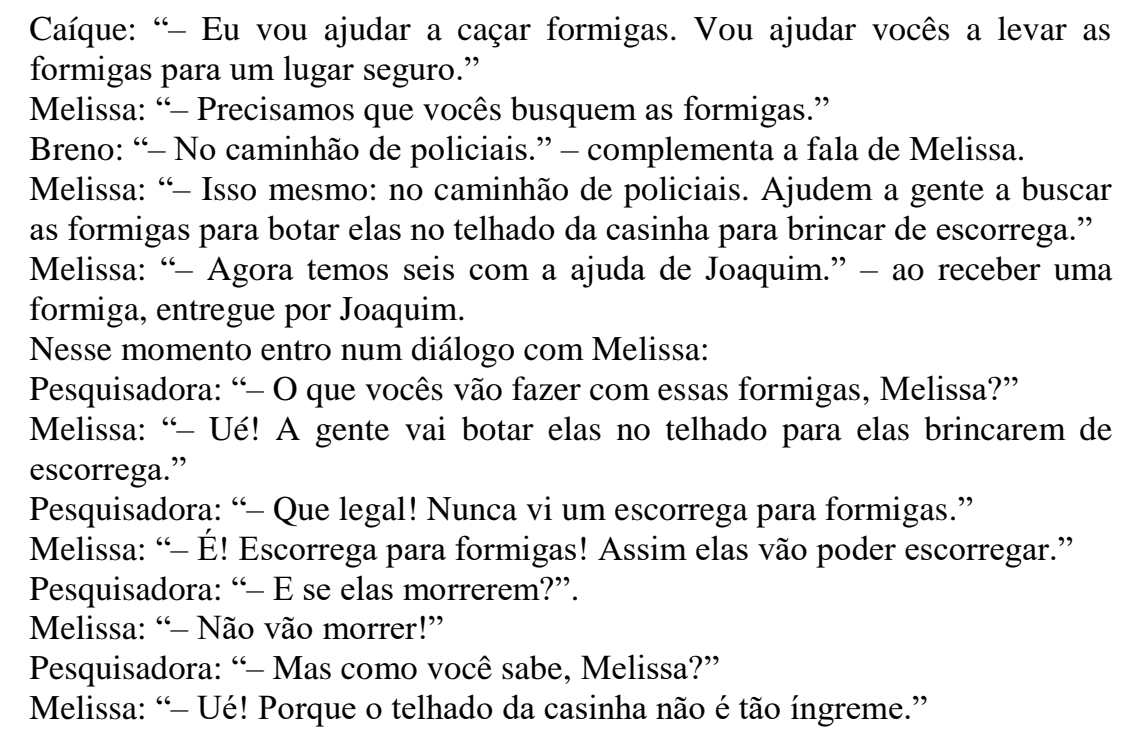

Logo em seguida, Caíque faz: "blu, blu, blu blu" (som de telefone). Ele segura o celular e fala: “- Capturem as formigas”!. E, juntas, as crianças levaram as formigas para a casinha de plástico e as colocaram no telhado. Olharam-me de longe, sorriram e vieram até a mim. Melissa me disse: “- o nosso plano deu certo! As formigas escorregaram em segurança". Esse relato vem para reafirmar, de acordo com Tiriba e Profice (2014, p.136) que precisamos de espaços e rotinas que sirvam à intenção de alimentar o amor à vida e à natureza.

Esse espaço possibilita a relação com a natureza, com as árvores, com insetos, com pequenos bichinhos que achamos nesse grande quintal. Nele, as crianças aprendem a importância de cuidar da natureza no contato com ela. Os corpos estão em liberdade, prontos para criarem, para se desenvolverem integramente.

A história da lagarta: “-Ela não queima. Eu descobri."

Marta me convidou para ver a lagarta que encontraram. Nesse momento, ela se colocou como minha ajudante. observava as crianças brincando, me seguia e dizia: “Vai! Escreve"! Ao me aproximar do grupo, coloquei o celular para gravar em áudio as conversas sobre a lagarta.

"- A lacraia vai te morder.".

Revista Interinstitucional Artes de Educar. Rio de Janeiro, V. 6, N.1-pág. 204-231 janeiro-abril de 2020: “Educação: Corpo em movimento II." - DOI: 10.12957/riae.2020.45751 
“- Não é uma lacraia! É uma lagarta!”.

“- Lagarta nem morde!”.

“-É, mas a lagarta queima, né?”.

“-É uma lagarta amarela!".

Caíque: "- Sai todo mundo de perto por favor!”.

“- Ela vai cair! Ela vai cair!” - diz outra criança, enquanto Caíque segura a lagarta na folha.

“- Ah! A lagarta caiu."

Marta me pediu que escrevesse lagarta em meu caderno de campo, e eu respondi: “- Tá bom, Marta! Estou escrevendo sobre a lagarta”. E a conversa continuou:

“- Gente! Eu também quero pegar ela!" - disse Nara.

“- Calma! - disse Laura - "- Todos estão querendo pegar ao mesmo tempo. Pega com uma folhinha, senão ela vai ficar assustada. É devagar, senão mata a lagarta.".

Laura continua dizendo para as crianças: “- Mas olha só! A gente não pode pegar qualquer lagarta não! Porque tem um monte de lagarta que queima”.

“- Essa não queima!" - responderam as crianças.

“- Não queima: eu peguei!” - disse Caíque.

"Essa não queima, eu descobri!" - finalizou Joaquim.

As crianças do grupo cinco aprenderam com o próprio corpo que nem todas as lagartas queimam a pele. Essa experiência, em contato com o conhecimento, pode ter passado por cada uma delas de forma diferente, pode até não ter passado por algumas, mas passou por mim, marcando-me, fazendo-me pensar e refletir na experiência de aprender em contato com a vida. Nesse sentido, segundo Larrosa (2002, p.27):

O saber da experiência é um saber particular, subjetivo, relativo, contingente, pessoal. Se a experiência não é o que acontece, mas o que nos acontece, duas pessoas, ainda que enfrentem o mesmo acontecimento, não fazem a mesma experiência. O acontecimento é comum, mas a experiência é para cada qual sua, singular e de alguma maneira impossível de ser repetida.

Esse momento pode ser definido como acontecimentos para algumas crianças e como experiência para outras. As situações nos atravessam de formas diferentes. Quem segurou a lagarta e disse “- Não queima, eu peguei!", aprendeu, no contato da lagarta com sua própria pele, que essas são marcas que podem ficar em nós por toda a vida. É o saber da experiência.

Além do brincar livre, pude observar momentos em que as professoras faziam intervenções com objetos e materiais. Essas intervenções possibilitaram diálogos, criações, brincadeiras entre diversas possibilidades criadoras das crianças em espaços ao Revista Interinstitucional Artes de Educar. Rio de Janeiro, V. 6, N.1- pág. 204-231 janeiro-abril de 2020: "Educação: Corpo em movimento II." - DOI: 10.12957/riae.2020.45751 


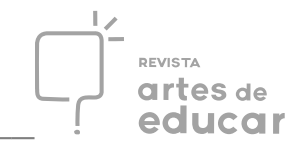

ar livre e com objetos pensados pelas professoras. Observei que pensar em um objeto não significa estabelecer o que vai acontecer, mas abrir a possiblidade para o novo, possibilidades de brincadeiras no pátio da escola que descrevo a seguir.

"Bolo durinho... bolo de verdade"

Entre colheres, panelas e peneiras de diversos tamanhos, próximos à terra e folhas que se transformam em "café, bolo de chocolate e pipoquinha", a imaginação permite que a pipoca vire comida e a mesma pipoca torna-se café novamente. “-Bolo de areia, bolo durinho, bolo para a Laura" - Diz a professora. As crianças dizem: “Olha, Laura! Aqui, bolo de verdade"!. Podemos perceber, assim, a importância de trazer objetos da vida das crianças para o espaço escolar (figuras 3 e 4).

Segundo Mastrascusa e Franch (2016, p.160), “na criança, a brincadeira é a mola mestra de seu desenvolvimento, de suas experiências com o mundo, colocando em jogo sua criatividade, sua expressividade psicomotora". A potência criadora delas flui com esses instrumentos, brinquedos não industrializados que permitem, no contato com a terra, a água e as folhas, a aprendizagem da vida com o viver e o brincar em liberdade.

Figura 3 - Entre terras, folhas e panelas

Figura 4 - Casinha

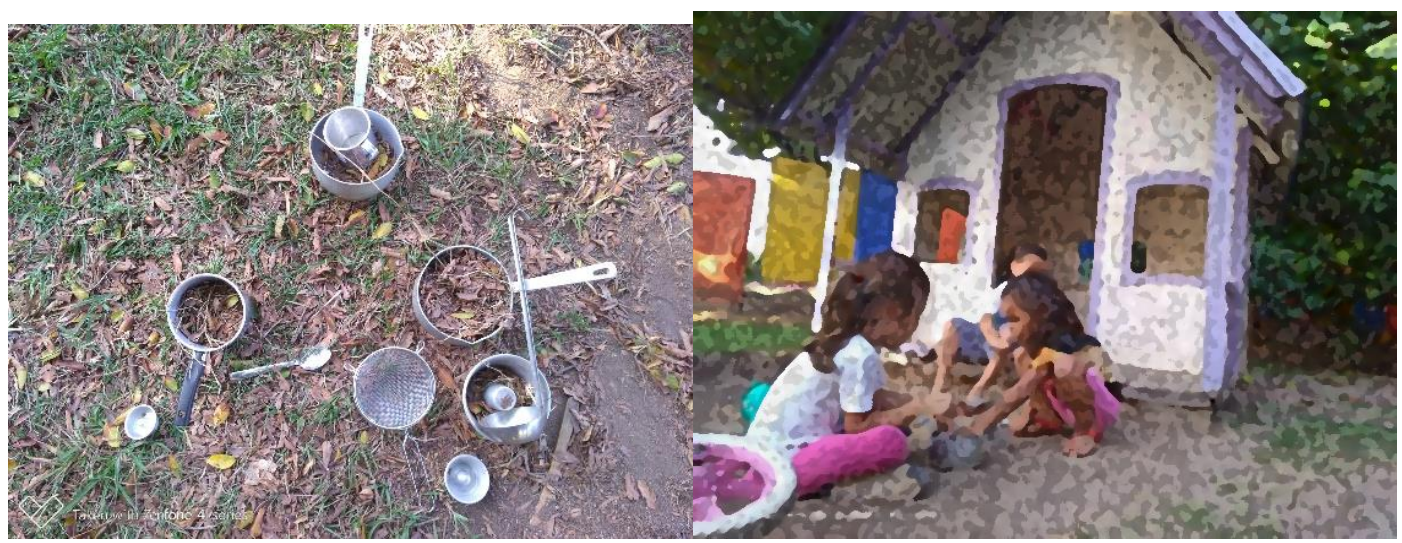

Fonte: Thomaz (2019)

Fonte: Thomaz (2019)

"Colar de folhas"

As professoras trouxeram barbantes e tesouras para a atividade. A intenção era construir colares de folhas:

Revista Interinstitucional Artes de Educar. Rio de Janeiro, V. 6, N.1-pág. 204-231 janeiro-abril de 2020: “Educação: Corpo em movimento II." - DOI: 10.12957/riae.2020.45751 
“- Eu quero uma pulseira e quero uma pulseira para o pé também” - disse Breno.

“- Pulseira para pé se chama tornozeleira!" - respondeu a professora Laura.

"- Achei uma folha grandona" - disse Joaquim, com a intenção de fazer seu colar.

Melissa fez uma tornozeleira de barbante e disse:

"- Tô com uma coisa tipo de índio".

“- Por quê?" - eu perguntei.

“- Índio também amarra barbante.” - Melissa respondeu.

Nesse diálogo, percebo como as crianças trazem diversos elementos e conhecimentos sobre o mundo em que vivem como "tornozeleira" e "pulseira para o pé”. Entretanto, prefiro aqui levantar questionamentos sobre as crianças e a concepção que elas e os professores tem sobre os indígenas. Será que eles amarram barbantes em seu corpo? Nós, professores, conhecemos a cultura indígena? Reproduzimos estereótipos? A curiosidade das crianças sobre esses seres humanos que assim como elas têm o desejo de estar em contato com a natureza deve ser percebida e aguçada pelas escolas?

Os indígenas permanecem com o desejo inato pelo mundo natural, enquanto muitos de nós o deixamos na infância. $\mathrm{O}$ amor pela natureza é o que nos permite cuidar do nosso lugar, assim como eles cuidam. Nesse caminho, dialogo com Tiriba (2018, p.231) sobre a importância de buscarmos:

recuperar o que os epistemicídios sempre intencionaram: a destruição de conhecimentos, saberes e de culturas não assimiladas pela cultura branca/ocidental; o emparedamento e apagamento da consciência de nossas origens ancestrais brasileiras, latino-americanas e caribenhas como força que nos permite continuidade histórica, como herdeiros de povos que sabem proteger o que é fundamental à continuidade da vida: as crianças e os territórios.

Desenho de corpos com giz no chão

As professoras levaram giz (normalmente utilizado para escrever em quadro negro) para usar com as crianças. Começaram, então, a surgir corpos desenhados no chão e crianças querendo que fizessem o seu contorno (figuras 5 e 6):

“- Olha! Olha o meu. É rosa!” - disse Nara.

“- Eu vou fazer uma pose Laura!” - disse Raissa, enquanto a professora contornava sua pose no chão.

Marta também faz uma pose e diz: “- Olha como ficou!”.

Revista Interinstitucional Artes de Educar. Rio de Janeiro, V. 6, N.1- pág. 204-231 janeiro-abril de 2020: “Educação: Corpo em movimento II." - DOI: 10.12957/riae.2020.45751 
Depois as meninas fizeram o contorno de Laura no chão, desenharam olhos, cabelo e pintaram o desenho bem colorido (utilizando azul, amarelo e verde). Chamaram a professora e disseram:

“- Laura, olha como você ficou! A gente rabiscou você!" - e começaram a rir.

Figura 5 - Brincando com giz no concreto

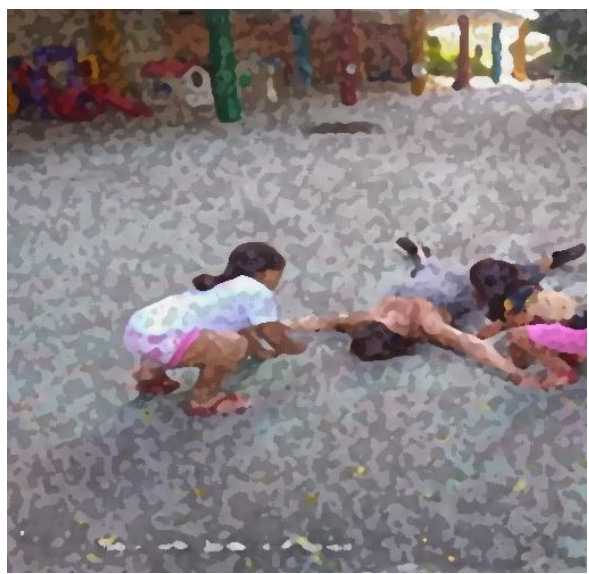

Fonte: Thomaz (2019)
Figura 6 - "A gente rabiscou você"

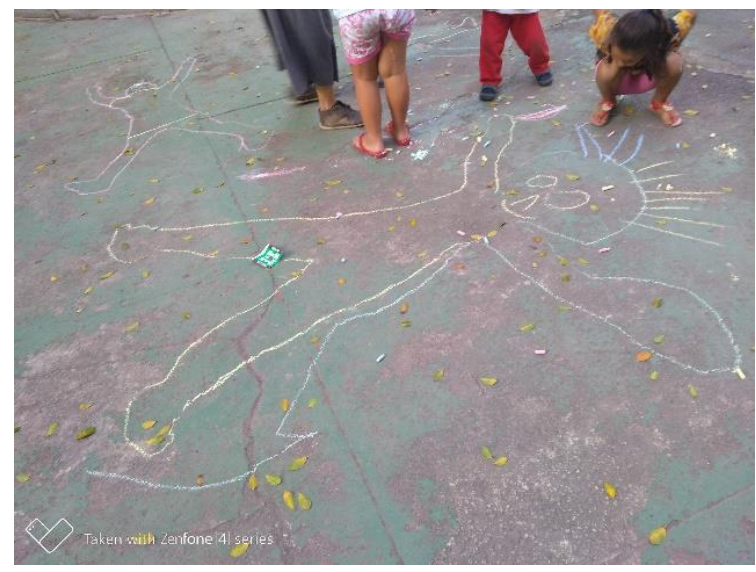

Fonte: Thomaz (2019)

Dessa forma, segundo Tiriba (2018, p.99), "as atividades ao ar livre proporcionam aprendizagens que se relacionam ao estado de espírito porque colocam as pessoas em sintonia com sentimentos de bem-estar". Ao trazer objetos, as professoras trazem intencionalidade para o seu trabalho, e as brincadeiras criadas são o que as crianças desejam fazer, ou seja, o que elas fazem, de fato, é do que gostam. Seria, então, a aprendizagem em contato com a alegria.

\section{Minhas intervenções no campo}

Após me relacionar com as crianças e observá-las brincando e criando com os objetos levados por suas professoras, planejei dois momentos de conexão com os elementos da natureza numa intervenção psicomotora. Nesse sentido, segundo Mastrascusa e French (2016, p.23):

A intervenção psicomotora no âmbito educativo é uma ação que pretende favorecer o desenvolvimento psicomotor da criança, acompanhando-a no itinerário evolutivo que deve conduzi-la do ato ao pensamento e do gesto à palavra, explorando de que se trata viver em um espaço e um tempo compartilhado com 'o outro'. 


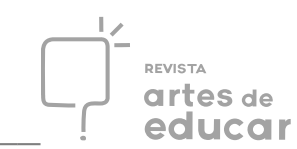

De acordo com os autores e pelo que vivenciei com as crianças, as intervenções psicomotoras propiciam conexão das crianças com elas mesmas, com os outros e com o meio. Permite o encontro com o próprio corpo e relações entre os gestos e as palavras, propiciando a alegria do viver.

Minha primeira intenção era a de coletar elementos naturais como folhas e gravetos para criarmos desenhos no chão. Porém, nesse dia, a chuva foi a novidade que chamou a atenção e curiosidade das crianças. Não teria como competir com a chuva, fenômeno meteorológico que as encanta. Como foi lindo observá-la junto com as crianças! Nesse dia, ficamos na parte coberta do pátio, e as crianças correram e brincaram no castelo de plástico.

Antes da chuva, o vento anunciou na escola que a sua chegada estava próxima e, com ele, algumas folhas caíram ao chão. Consegui então propor a um grupo de quatro crianças que pudéssemos experimentar os elementos, folhas e gravetos. Tinha como objetivo construir desenhos no chão, mas elas deram outro sentido ao que havia planejado: "A festa do meu filho". Nessa festa, os elementos naturais foram utilizados para construir bolo e brigadeiros: “- olha o cheiro! Olha o cheiro! É cheiro de brigadeiro"! - disse Nara. A intencionalidade dessa vivência vai ao encontro da compreensão do espaço escolar como volume, explicitado por Lapierre e Aucouturier (2004, p. 58): espaço escolar, o espaço gráfico, aquele do caderno e do quadro negro, é um espaço-plano. É necessário sair desse espaço "plano” para redescobrir a riqueza do volume, de um mundo em três dimensões, que é o mundo da vida.

Vivemos num mundo em três dimensões, e limitar o ato das crianças de conhecê-lo em folhas com pautas é limitar a vida delas. Descobrir o mundo em contato com a natureza é aprender em três dimensões, como os autores propõem no estudo que fazem sobre a simbologia do movimento.

Para o segundo dia de intervenção psicomotora no contato com a natureza, levei argila, bacias e água (figuras 7 a 9). A intenção era a de deixar que as crianças experimentassem aquela lama. Ao chegar no pátio, o grupo já estava lá, uns corriam, outros subiam a colina e cinco crianças vieram atrás de mim para saber o que eu tinha: “- Água”! Logo, exclamou uma das crianças: “- sim! Água e argila”! Com isso, escolhemos um espaço no pátio para iniciar nossa bagunça. O grupo que se interessou 


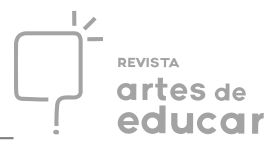

pela argila entregou-se de corpo inteiro. Iniciamos com as mãos, logo os pés entraram na bacia e depois éramos todos compostos por barro.

\section{Figura 7- Lambança}

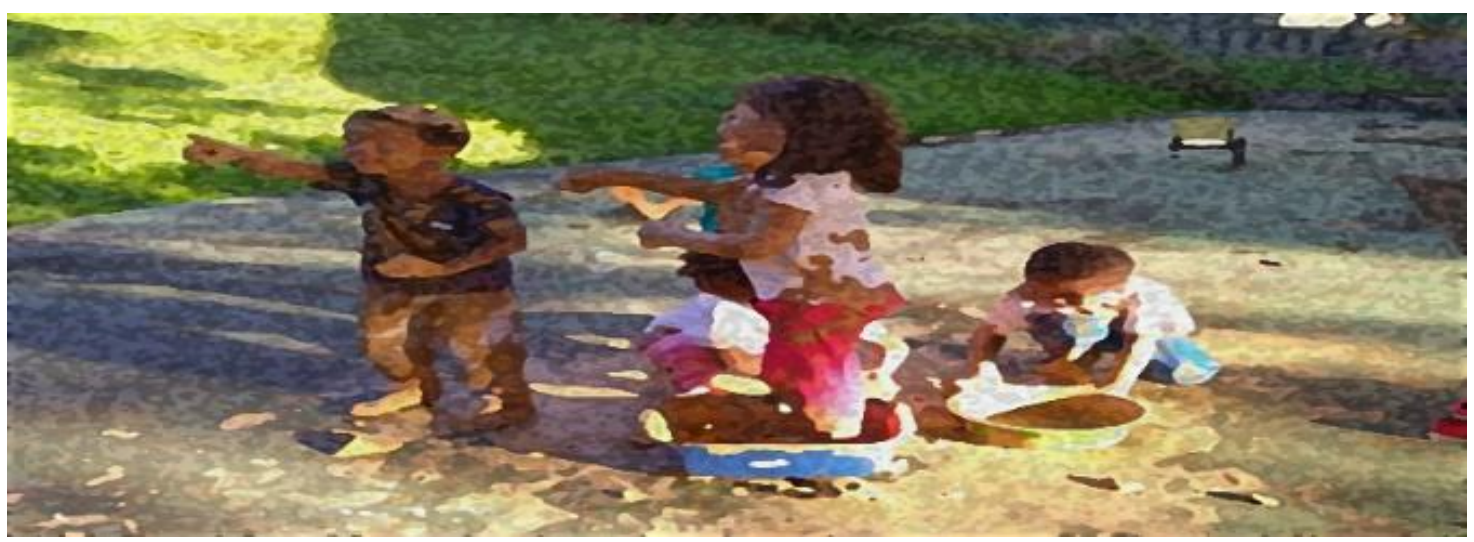

Fonte: Thomaz (2019)

Figura 8 - Com os pés no barro Figura 9 - Corpo que transborda

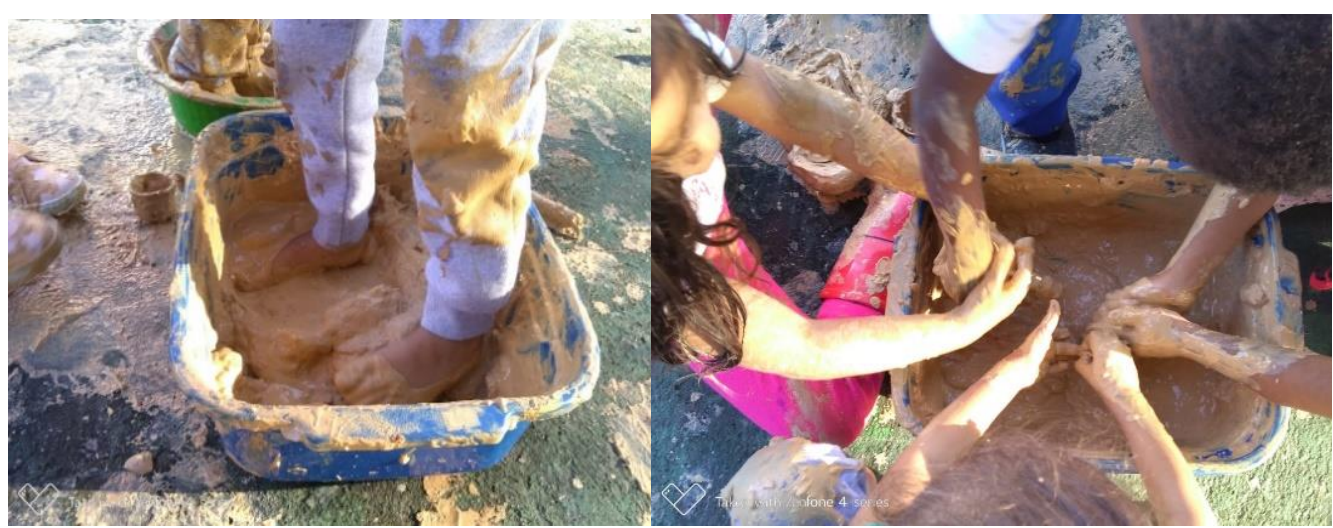

Fonte: Thomaz (2019)

Fonte: Thomaz (2019)

Essa vivência de conexão mostra, de acordo com Tiriba (2018, p.70), como as crianças gostam de se sujar, de se lambuzar, de se misturar com aquilo com o que brincam, no caso, os elementos do mundo natura. Brincar com a argila é se conectar com o que somos, é sentir uma alegria que transborda pelo corpo, sendo demonstrada por sorrisos, olhos que brilham e movimentos corporais que demonstram o que somos em essência: corpo e natureza.

Vou descrever detalhadamente esse momento de muita alegria e conexão. Começamos colocar água na argila e amassando-a com as mãos, logo, tínhamos camadas de barro nas mãos e a bacia de água foi transformada em uma "piscina de 


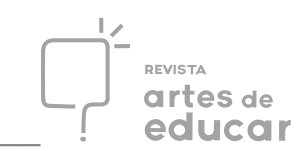

lama”, de acordo com Daniel. Os pés entraram nessa piscina e escorregaram pela bacia e pelo chão numa exploração corporal pelo espaço. Surgiu, nesse momento, o desejo de espalhar a lama pelo corpo, pelo rosto, pelas mãos e cabelos e, assim, as crianças ficaram cobertas por uma camada de barro que as constituíam e as deixavam alegres. Os sorrisos eram constantes, porém, às vezes, eram interrompidos por pensamentos como: “- Minha mãe não vai gostar de ver minha roupa assim”, "- Minha mãe vai brigar comigo”, “- Minha mãe não vai gostar”, mas logo a alegria voltava a dominar a cena e as crianças exploravam isso ainda mais, Exploraram de corpo inteiro e me perguntaram se eu poderia me sujar também. Nesse momento, minhas mãos e roupas já estavam cobertas por lama, mas eles falavam sobre o meu rosto. Foi aí que surgiu o desejo de me maquiar com argila. As crianças passavam a argila em meu rosto com carinho. Era interessante sentir as pequenas mãos e o barro em contato com minha pele.

Para finalizar nossos encontros, planejei uma roda de conversas debaixo da maior árvore de nosso quintal, mas as crianças queriam correr, então, não lhes pedi para fazer a roda. Nesse dia, pude testemunhar o interesse pela colina que as professoras mencionavam. As crianças subiam, desciam e rolavam (figura 10). Fui convidada a rolar, mas disse a eles que tinha medo. “- Medo? Nós somos crianças e não temos medo. Você não deve ter medo, você é adulta!" - me disse Melissa. E eu disse para ela que tínhamos que aprender com as crianças a ter coragem. Elas insistiram e lá fui eu descer o morro rolando. Ensinaram-me a técnica de rolar: “- Primeiro o corpo fica reto e depois...". Bom... não teve depois, pois fui empurrada lá de cima, desci rolando um morro pela primeira vez. Foi uma sensação de alegria, euforia e tontura. Vi tudo muito rápido, poderia dizer que foi uma experiência única em minha vida, mas as crianças pediram: “- De novo, de novo!”. Assim, fomos mais uma vez.

Após essa experiência indescritível, coloquei folhas no tamanho A3, canetinhas e giz de cera no chão e, aos poucos, as crianças se aproximaram. Em pequenos grupos, conversaram comigo sobre a finalização da pesquisa. Pedi que desenhassem do que mais gostavam no pátio (figura 11). Surgiram flores, céu, e a maioria das crianças desenhou o local em que estávamos, em frente à colina. 


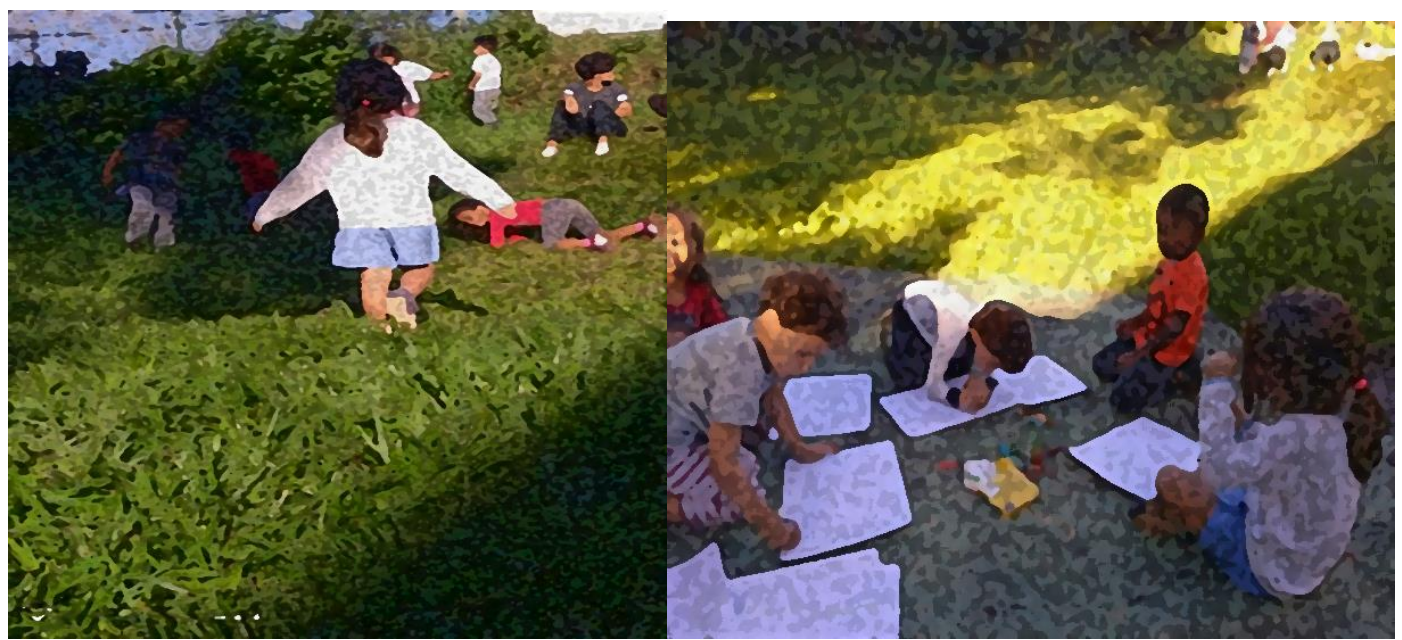

Fonte: Thomaz (2019)

Fonte: Thomaz (2019)

Melissa: "- Sabe o que que é isso?"

“- Não" - eu respondi.

“- Ué, é o céu, para representar o céu de verdade."

“- E onde está o céu de verdade?" - eu indaguei.

"- Em cima da gente" - respondeu Melissa.

“- E esse morro?".

“- É para representar aquele morro ali”.

“- E vocês gostam daquele morro, grupo cinco?”.

"- Sim" - responderam as crianças.

“- Esse desenho é seu, Joaquim?” - eu perguntei.

“-É!”.

“- E o que você desenhou aqui?".

“- As flores!".

“- Tem flores aqui no pátio?”.

“- Tem. Olha as roxas ali!" - disse Daniel.

Nesse momento, eu vi flores roxas no alto da colina, flores que eu nunca havia visto na escola, o que me fez refletir sobre como as crianças enxergam detalhes que não nos detemos no dia a dia. Como elas são felizes em contato com a natureza e como ainda estão interligadas com a essência de suas vidas.

“- E você, Daniel, desenhou o quê?”.

"- O céu, os passarinhos, as águas, a árvores, o sol! O sol!”.

Logo Melissa pediu: “- Me empresta o amarelo, Breno!”.

E assim seguiram, usando amarelo, verde e azul, desenhando a natureza em que estávamos insertos naquele momento.

Com a experiência dessa pesquisa, houve uma imersão no mundo da brincadeira ao ar livre no nosso quintal (pátio da escola). Assim, compreendo e alio-me ao pensar de Tiriba (2018, p.235) ao afirmar que é fundamental investir no propósito de Revista Interinstitucional Artes de Educar. Rio de Janeiro, V. 6, N.1-pág. 204-231 janeiro-abril de 2020: “Educação: Corpo em movimento II." - DOI: 10.12957/riae.2020.45751 


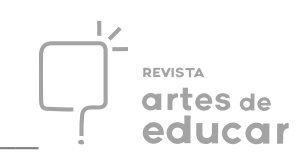

desemparedar e conquistar os espaços que estão para além dos muros escolares, pois não apenas as salas de aula, mas todos os lugares são propícios às aprendizagens.

O que destaco neste texto são as múltiplas possibilidades de aprendizagens, conexão e trocas afetivas propiciadas no pátio da Educação Infantil do Colégio de Aplicação da Universidade Federal do Rio de Janeiro (UFRJ).

Em síntese, o presente estudo trouxe contribuições para a área da Psicomotricidade e Educação. O trabalho buscou trazer reflexões sobre corpo, natureza e infância, dialogando com autores que já escreveram sobre a importância das relações com o ambiente natural. Essa escrita é fruto das aprendizagens no curso de especialização em Educação Psicomotora do Colégio Pedro II e das leituras que busquei para aprofundar o estudo sobre corpo e natureza.

Neste trabalho, pude apresentar a Educação Infantil como lugar de alegria, espaço em que as relações potencializam os seres: crianças e professores. Corpo que não é "docilizado", que se movimenta e, em movimento, aprende, conhece, cria, inventa e se alegra.

O espaço ao ar livre proporciona as crianças compreender que nem todas as lagartas queimam! Possibilita construir um desenho em que flores nunca vistas pelos professores sejam retratadas pelas crianças. O olhar da infância vai ao encontro da natureza da qual ela faz parte. Ele é sensível ao mundo natural e cabe aos professores potencializarem o desejo de se relacionarem com outras formas de expressão da natureza.

Ir à campo, mesmo sendo professora nesse espaço, me permitiu olhar para o pátio da escola como o lugar de encontros. Pesquisar é a ação de produzir conhecimentos e, nesse caso, para além de construir novas teorias para repensar a instituição escolar, essa pesquisa me proporcionou sensibilizar ainda mais o meu olhar para os desejos das crianças. Eu compreendi também a importância de o professor aceitar o convite para brincar junto. As crianças nos convidam e nós educadores vamos brincar?

Em suma, desemparedar os seres humanos é colocá-los em relação com o ambiente natural. A escola é o espaço possível para que as crianças estejam em contato com a sua essência. Antes de me despedir desta escrita, sinalizo que foi difícil escrever, como em todo ato criador, mas que a alegria em conseguir expressar nas palavras o que 


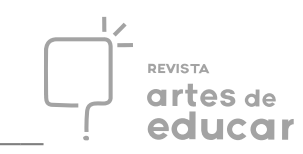

acredito e o que senti ao fazer a pesquisa é inenarrável. Desejo que crianças e professores tenham mais tempo para olhar passarinhos, borboletas, formigas e árvores.

\section{REFERENCIAS}

BARROS, Manoel de. Memórias inventadas: as infâncias de Manoel de Barros/iluminuras de Martha Barros. - São Paulo: Editora planeta do Brasil, 2008.

BRASIL. Lei de Diretrizes e Bases da Educação n 9.394, de 20 de dezembro de 1996. (1996). Disponível em:

$<$ https://presrepublica.jusbrasil.com.br/legislacao/109224/lei-de-

BRASIL. Resolução n ${ }^{0}$ 5, de 17 de dezembro de 2009: fixa as Diretrizes Curriculares Nacionais para a Educação Infantil. (2009). Disponível em:

$<$ http://portal.mec.gov.br/index.php?option $=$ com_docman\&view $=$ download \&alias $=229$ 8-rceb005-09\&category_slug=dezembro-2009-pdf\&Itemid=30192>. Acesso em $16 / 01 / 19$.

DIONNE, Hugues. A pesquisa: ação para o desenvolvimento local. Tradução: Michel Thiollent. Brasília: Liber livro Editora, 2007.

EEI-UFRJ. Escola de Educação Infantil - UFRJ. (s/d). Disponível em: $<$ http://eei.ufrj.br/index.php/2016-04-05-16-22-59/historia>. Acesso em 20 de julho de 2019.

FOUCAULT, Michel. Vigiar e punir: nascimento da prisão. Trad. Raquel Ramalhete. 36.ed. Petrópolis, RJ: Vozes, 2009.

GALVÃO, Izabel. Henri Wallon: uma concepção dialética do desenvolvimento infantil. 20ed. Petrópolis, RJ: Vozes, 2014.

GUATTARI, Félix. As três ecologias. Tradução de Maria Cristina F. Bittencourt. 21.ed. Campinas, SP: Papirus, 2001.

LAPIERRE, Andre; AUCOUTURIER, Bernard. A simbologia do movimento: Psicomotricidade e educação. 3.ed. Curitiba: Filosofart, 2004.

LARROSA, Jorge. Notas sobre a experiência e o saber da experiência. Revista Brasileira de Educação.v.11. jan/abr. 2002. Disponível em:

<http://www.anped.org.br/rbe/rbedigital/RBDE19/RBDE19_04_JORGE_LARROSA_B ONDIA.pdf $>$. Acesso em 01 de março de 2019. 
MASTRASCUSA, Celso; FRANCH, Núria. Corpo em movimento, corpo em relação: Psicomotricidade Relacional no ambiente educativo. São Paulo: Evangraf, 2016.

PROFICE, Christiana. As crianças e a natureza: reconectar é preciso. São Paulo: Pandorga, 2016.

QUEIRÓS, Bartolomeu Campos de. Os cinco sentidos. São Paulo: Cia. Editora Nacional, 2004.

SCHAEFER, Katia de S. A. Bizzo. Afetos que emergem de práticas educacionais a partir da reconexão de corpos e ambientes: uma questão de transvisão e transvaloração do mundo. In: Anais do $5^{\circ}$ GRUPECI - Seminário de Grupos de Pesquisa sobre Crianças e Infâncias. Florianópolis: UFSC, dez/2016.

TIRIBA, Lea. Educação infantil como direito à alegria. Petrópolis, RJ: Paz e Terra, 2018.

TIRIBA, Léa; PROFICE, Christiana. O direito humano à interação com a natureza. In: SILVA, Ainda Maria Monteiro; TIRIBA, Léa (org.). Direito ao ambiente como direito à vida: desafios para a educação em direitos humanos. São Paulo: Cortez, 2014.

\footnotetext{
' Possui graduação em Pedagogia pela Universidade Federal do Rio de Janeiro (2017). Especialista em Educação Psicomotora pela Pró-Reitoria de Pós-Graduação, Pesquisa, Extensão e Cultura (Propgpec) do Colégio Pedro II. Cursa mestrado em Educação pela Universidade Federal do Estado do Rio de Janeiro (UNIRIO), participa do grupo de pesquisa GITAKA: Infâncias, Tradições Ancestrais e Cultura Ambiental junto à professora Lea Tiriba. E-mail raiannebernardo95@gmail.com. ORCID: https://orcid.org/0000$\underline{0003-2734-4885}$
} 